\title{
Vegetable oils for transportation fuels - the bus we missed
}

\author{
Shrinivasa Udipi* \\ Formerly Department of Mechanical Engineering, IISc, Bengaluru 560 012, India \\ Present address: Peach Engineering Pvt Ltd, Bengaluru 560 092, India
}

THE beginning of the 20th century witnessed many thinkers concerned about the problem of widespread poverty. Ruskin's Unto This Last in 1860, became Sarvodaya for the Gandhians from 1908 onwards. Contrarily, the socialist approach of centrally controlled development was advocated by Jawaharlal Nehru and his planning committee. Post-independence, this planning committee became the Planning Commission and India continued with investments in steel, cement, fertilizers, electricity, heavy industry, etc. The achievements and shortcomings are discussed in a survey article by Bhatt ${ }^{1}$, covering about six decades, from the beginning of the Sarvodaya concept to the Planning Commission becoming a dominant player for economic development in India. Gopinathan Pillai ${ }^{2}$ provides further analysis of India's development process.

Early Gandhians however continued to pursue Sarvodaya. To be fair the state did provide some support for this movement as well. The Khadi and Village Industries Commission (KVIC) was set up in 1957. Some institutions to specifically promote Sarvodaya concepts, were established. However, on what exactly had to be done to bring about poverty reduction by gainfully employing the poor, that key was difficult to find. Many intellectuals in India took to discussing how to approach Sarvodaya during the early decades after independence. In this regard, there was already the leadership provided by Mokshagundam Visvesvaraya in the State of Mysore. Krishna Raja Wadeyar IV, a benevolent king and his highly professional Diwan, Visvesvaraya, who was also a brilliant engineer, had built dams across the mighty rivers Cauvery and Thungabhadra, when no Portland cement was available, providing irrigation water to the thousands of farmers with dry lands and transforming the landscape. They had also built a steel mill to use locally available iron ore and established a supply chain for charcoal for the mill from a dedicated forest. They set up sugar mills to absorb the excess production capacity of the now irrigated lands, producing sugar as well as ethanol from the molasses, and so on. Thus with science and technology (S\&T) inputs and using locally available resources, it was clear that livelihoods to a large number of people could be made available.

However, after independence this role became the monopoly of the Planning Commission and the Govern-

\footnotetext{
*e-mail: udipi.shrinivasa@gmail.com
}

ment of India (GoI). How long would Sarvodaya take with the limited finances of $\mathrm{GoI}$ and a rapidly multiplying population? As long as Mahatma Gandhi was present, he was worrying about 'bread labour' for the poor; however, his spinning wheel was woefully inadequate for the purpose. He even thought that the wheel could be mechanized; but that would hardly suffice for providing livelihoods to the 300 million people who needed them. India needed help from experts in S\&T to develop new concepts akin to the spinning wheel, with their skills and knowledge.

Post-independence when the nation started heading towards industrialization, there were many who had not forgotten the need for bread labour. One such, supposedly known as the Bombay-Bangalore group, met alternately in the two cities to discuss developing technologies useful to the rural poor. Their efforts made a group-member pursue electricity from photovoltaics to prominence, while another could extract silicon from rice husk ash, leading to industrial-scale production for making photovoltaic cells.

As students in the Indian Institute of Science (IISc), Bangalore campus in the early 1970s, one would hear rumours that our Director, Satish Dhawan, was also participating in the discussions going on in this group. Our hunch got further support when, in the weekly seminars, one got to hear about a number of topics related to technologies for rural areas. The intensity of the discussions during these seminars began to draw in participants from many disciplines. And all this churning led to the establishment of a cell (a minor department which could grow into a full-fledged one based on its performance), viz. 'Cell for the Application of Science and Technology to Rural Areas' with an acronym ASTRA, pronounced the Sanskrit way. Thus with participants from differing science and engineering backgrounds getting involved, the focus was on 'application' to rural areas creating a new 'appropriate technology' movement. In all this, Ruskin's Unto The Last was left by the wayside, and could only hope for more compassionate believers in the future. The redeemer would finally come, 70 years after independence, in the form of the Government of India (GoI).

Developing appropriate technology concepts requires resources. With Dhawan's backing many departments 


\section{SATISH DHAWAN BIRTH CENTENARY}

shared building space, equipment and some of the testing facilities. The Government of Karnataka helped by leasing a 60 -acre farm in a village called Ungra in Kunigal taluk, about $150 \mathrm{~km}$ from the IISc campus, at least $3 \mathrm{~h}$ away in an ambassador car. Any progress now required money, with all other things being in place.

Again Dhawan, with the enthusiastic support from some colleagues, established a unique institution in the campus, actually belonging to the Government of Karnataka to promote S\&T applications in the state, in collaboration with the Department of Science and Technology (DST), GoI. This exceptional collaboration between IISc and the Government of Karnataka, viz. Karnataka State Council for Science and Technology (KSCST) had a mandate to give $40 \%$ emphasis to rural problems. The early enthusiasts of appropriate technology could apply to KSCST for small grants which were dispersed within a few months. Additionally, KSCST would administer the funds which was a great help because to that extent IISc was relieved of dealing with very small projects. Thus the creation of KSCST encouraged seeding of quite a number of appropriate technology projects. A few progressed into highly professional groups like 'alternative building technologies' and 'combustion and gasification technologies'. In addition, a significant volume of research publications came from them as well as a good number of research degrees. As with many of Dhawan's initiatives, this approach was truly visionary, as even today, with talk of agile design and technologies, the biggest stumbling block is frequently a lack of funding for small projects.

In addition to being the Director of IISc, Dhawan also took up the responsibility of Chairman of the Indian Space Commission in 1972, which rather unexpectedly, brought him face to face with what could be a Sarvodaya project that the organization had been pursuing. How it all started at the Thumba Equatorial Rocket Launching Station (TERLS) reads more like a fairy tale that was so amazing, that it was most probably never recorded. It is, however, probably still not too late to collect the bits and pieces from the surviving members of the team. I came to hear of the events nearly two and a half decades after they unfolded, when they were narrated to me by a visitor to my laboratory in IISc, who was from that very group. Some part of it was also repeated by Dhawan himself when he visited me in my laboratory, shortly before 2000 .

Just around the first week of January 1969, a visit to TERLS was arranged as part of an educational tour for the final year BTech students of the Department of Aeronautical Engineering at IIT Madras. Besides other places, which were not many, the youngsters were shown around the facilities of a group for propulsion chemistry that had just been put together. The head of the group himself took the batch around. One of the priorities of the group, he said, was indigenization of the fuels for rocket engines. Thirty years later my visitor from the same propul- sion group observed that the focus had been pursued vigorously, making experiments with different locally available candidate fuels, including various vegetable oils, edible or otherwise. To begin with a column was set up by a chemical engineer from the team to modify the raw oils from the market and soon they were able to get a thin volatile liquid which interested everyone. They thought it may be a fuel suitable for automobile engines and therefore, a sample should be sent to IISc to get it tested. The task was given to the only mechanical engineer among them who became known to the present author in IISc. If the results of the tests could come back before the next visit of the Chairman of ISRO, then Vikram Sarabhai, a presentation could be made to him. But the sample did not go for testing and the days went by. The Chairman's visit got scheduled and the sample had not left the laboratory. Then all of a sudden his arrival got advanced and now it was the next day.

Thus, on the morning of the day of the Chairman's visit, all the colleagues had arrived early and the question going around was, 'what has been done with the fuel sample?'. The afore mentioned mechanical engineer being cornered like this, quietly emptied all the petrol from his scooter and filled its tank with the material meant to be sent for testing. He tried to kick start the engine and to his surprise the scooter started. He took it for a ride around the IISc campus and found the vehicle behaving satisfactorily. He then briefed the group about his experiment and rode the vehicle around as a demonstration. One of the teammates wanted to ride on the pillion to get a feel of how the engine was behaving and he was taken around a few times. The rest of the members too queued up, each for a few rounds on the pillion and they together reported to the Head. He also wanted to get a pillion ride at the end of which the group decided that the performance was satisfactory and the preliminary results could be presented to the Chairman that day. During the review, the Chairman appreciated the scooter carrying the rider and the pillion going around with indigenous fuel and expressed his keenness to offer himself as the pillion. This, however, the team decided was a risky proposal and they therefore looked for a four-wheeler which would be safer. The only one around was the Chairman's ambassador. The driver was somehow convinced to empty his fuel tank and fill it with the sample. The car started without trouble and the Chairman was happy about his experience with the ride.

As a result, the product was to be thoroughly analysed and tested and further the process was to be standardized. Sarabhai recommended setting up a pilot plant at Ahmedabad, in the Space Applications Centre (SAC). The seed could be collected from the surrounding forests and the fuel could be used for vehicles in SAC. While the programme was in the take-off stage, however, Sarabhai passed away rather unexpectedly, and Dhawan took over as the Chairman of the Space Commission. 
In the next review meeting details of the new fuel were presented, including the episode of the Ambassador car running on it. The programme received instant appreciation and whole-hearted support from the new Chairman, Dhawan. For him, after all the searching, here finally was a Sarvodaya project. The poor could collect the seeds, dry them, bag them, aggregate and sell them. Seed cakes could be brought back to the villages and sold as natural fertilizer and pest repellent (a commonly prevalent practice already). Small industries could process the oilseeds and the oil would be transformed into 'space crude', refining which standard gasoline could be produced which had an ever-increasing market. Therefore, no one need to worry about who will buy the outputs of the bread labour. At least during the seed harvesting season, the poor could earn some income.

A pilot plant was set up and with the backing of Dhawan, it ran successfully for a few years. Now it was time for multi-location field trials for which a Rs 250 crores proposal was made. The success of the pilot-plant operation and the plan for extended field trials were the subject of the Laksmanaswamy Mudaliar Memorial Lecture delivered by Dhawan at IIT Madras, probably in 1978. The lecture notes were printed and circulated; however, after 42 years any surviving copy is difficult to find and I could not trace mine.

Following the standard procedures of the Department of Space and the best traditions of project review, the proposal was looked at by several experts. The production process was clear; but collecting the volume of oilseeds from remote tribal areas was difficult and expensive. The cost of the end-product came to about Rs 4 per litre, whereas petrol was available in the market for less than Rs 2 per litre. The result of this was a negative verdict on pursuing multi-location trials and space crude was dropped from the agenda along with an opportunity for helping Sarvodaya.

Unfortunately social wisdom and the application of modern technology do not automatically come together. Choices have to be exercised and these require, apart from scientific knowledge, social, political and economic judgement. These were statements made by Dhawan in 1983 at the Lal Memorial Lecture in New Delhi.

Another group that grew out of ASTRA was that of biomass gasification, headed by H. S. Mukunda. I was a senior research fellow in ASTRA and was assigned the task of studying the literature and designing a gasifier which could use wood and supply fuel to a $5 \mathrm{hp}$ diesel engine. Earlier models were for 20 to $200 \mathrm{hp}$ whereas most irrigation pumps in India were $5 \mathrm{hp}$. The design was ready and a prototype was fabricated. To test it however, additional subsystems were required along with space, manpower and working expenses. Mukunda came to shoulder the responsibility and KSCST sanctioned a project. A test rig was put together with a burner, chimney and a blower, and the reactor was ignited; surprisingly, the gas started burning steadily. To check its reliability, the reactor was not stopped for $24 \mathrm{~h}$ and the performance was satisfactory.

The development work was started with funding from KSCST and field trials conducted in several hundred places under a subsidy programme from the Ministry of Non-Conventional Energy Sources (MNES), GoI. The results from the field were different from what was expected. Even though the package consisting of the reactor, diesel engine and pump for supplying irrigation water worked well with wood pieces as fuel, with pilot diesel support for engine combustion, the users found it convenient to run the engine on full diesel, an expensive option. For a typical pumping of about $1000 \mathrm{~h}$ yearly, requiring about Rs 7000 worth of diesel, saving $80 \%$ of diesel cost was not interesting to the farmers, except during times of diesel scarcity.

There were requests for scaling up of the system for rural and semi-urban use. The design review of the first $100 \mathrm{~kW}$ system put together by the present author (Mukunda was on sabbatical) was chaired by Dhawan. The system was built and shipped to Port Blair in the Andaman Islands.

It is about 40 years now since the first prototype gasifier underwent testing. The present group could offer designs of the reactors for energizing engines for up to $1 \mathrm{MW}$ electricity. They now have units with oxy-steam reactors whose output gas composition can be tuned. These are useful for gas-to-liquid conversions.

Still pursuing the bread labour requirement, a village production system was conceived in IISc. In this system, rainwater is harvested and stored within the village boundaries. This stored water is used for life-saving irrigation of food crops, and for irrigation of cash crops like mulberry, whose leaves are used for silk-worm rearing, thus keeping agricultural family labour fully engaged. A system of bore wells to pump up irrigation water as required, and an arrangement to collect excess rainwater and charge the same bore wells to replenish them, were also part of this model. Any biomass wastes generated would be gasified to obtain energy for water pumping. With a user group formed, whose members agree to pay for the water used, the idea was to recover the investment in about four years.

The recovered capital could now be invested in another village, leading to a bootstrap development model which would be sustainable.

The concept called sustainable transformation of rural areas (SuTRA, again pronounced the Sanskrit way) got support from the Government of Karnataka, Rural Development and Panchayat Raj Department (RDPR), with contributions from the (now) Ministry for Nonconventional and Renewable Energy Sources (MNRE), GoI. SuTRA was to be implemented in a set of villages near Ungra. All the components of the system were put together in the field and each ascertained to be working, 


\section{SATISH DHAWAN BIRTH CENTENARY}

including purchase of irrigation water by the villagers. Now it was time to go for a three-year proofing run. The funding agencies reviewed the system put together in the field and found it to be working, but decided that such concepts would be difficult to propagate. Therefore, SuTRA did not get further support and had to be abandoned and a déjà vu as far as Sarvodaya was concerned.

Rural development as we knew of the Sarvodaya, is such a tantalisingly and inviting problem to solve, that it is difficult to stop looking at it, despite all the roadblocks. During SuTRA fieldwork in the villages, the little group involved often had to travel to and fro from Bangalore to the worksite. On such trips, usually quite crowded with knowledgeable people, eager to make a difference, there would be serious discussions about the project implementation. On one such return journey, the question came up about what one would do if diesel became unaffordable since even power generation using gasifiers crucially required about 20\% diesel support. Vaguely recollecting, from the course on IC engines, that vegetable oils could substitute diesel, I mentioned it to the group. There was total disbelief and the rest of the journey went in discussing the impossibility of such an alternative. The next morning, an enthusiastic group of SuTRA project staff was already in the vehicle to go to the project site, with several 201 cans of different vegetable oils (pongamia, neem, mohua and castor), all bought from the local market. On reaching the site, which had diesel engine gensets meant for pumping drinking water to the villages and for providing lighting for a few hours in the evening, one diesel engine was chosen for the trial. These engines had provisions added to measure fuel consumption. The fuel tank was filled with the oil, thinner ones directly and the more viscous ones after heating and thinning down. The group was surprised to find the engine running comfortably and its oil consumption levels comparable to that with diesel. The villagers who were watching the trials were equally surprised. They told us in no uncertain terms that such a simple alternative should be pursued in the project. We had paid nearly thrice the price of diesel for the oils. The villagers pointed out that the oils will be a lot cheaper in the villages. These were their lamp oils before kerosene came and the trees are present in most villages. They helped us to locally purchase about 80 tonnes of pongamia seeds in a short time and when these were crushed, the oil yield was better than $30 \%$. With the seed cake sold back to villagers, which was their traditional fertilizer, the cost of the oil was only a fraction of the diesel cost.

This demonstration and our preliminary observations got wide publicity across the nation and even abroad. The fact that these trees are everywhere and more can be grown, where possible, thus providing a significant alternative to diesel, attracted widespread interest. A large number of engine specialists and fuel chemistry experts started investigating the alternative and the fact that these oils were historically used before diesel fuel, helped in its gaining early popularity in the scientific community. Their combined wisdom recommended biodiesel, which is an ester of these oils, whose properties closely matched that of diesel. ASTM came up with the draft standards for biofuels. Today many countries have finalized standards for biodiesel, which makes it possible to manufacture and sell, and also recommend suitable blends with diesel for different engines. In India, DST funded creation of research groups in national institutions for this purpose. BIS has also come up with biodiesel standards.

While these developments were going on, and just prior to 2000, Dhawan visited me in my laboratory with some of his colleagues involved in space crude. After discussing about the new alternative from SuTRA the whole afternoon, as he left he advised me to pursue it and 'never give up'!

Still on this 'pursuit' track, we got an opportunity to make a presentation in a competition called the 'Development Market Place' at World Bank. Amongst the many visitors to the cubicle, which was managed by the present author and Nayeem (who was a mainstay of the SuTRA project, which he administered ably along with looking after its finance management, which is always critical), was the President of World Bank. After hearing us he requested us to not to leave the booth until he comes back and after a few hours brought with him the Assistant Secretary of State for Energy, asking us to give him a detailed presentation. After listening to us he wanted to know how the US can use the alternative. On being told that vegetable oil production is a huge farm sector in the country, and that thinking of using these oils as fuel would also cushion them from the ups and downs in oilseed production, he thanked us and they both left. In just a few months after this, USA brought in the Jobs Bill offering US\$ 1 tax credit for every gallon of biodiesel blended. The preamble to the Bill spoke about reducing imports and encouraging local production with an aim to produce more jobs in the rural areas just like a Sarvodaya component. It is the largest subsidy programme for biodiesel and has been continued for more than 14 years.

In India, the Government however, would not respond so favourably for a long time amidst opposition from oil marketing companies worried about losing their monopoly over fuel oils. Luckily help came from an NGO working on environment and conservation of the Western Ghats led by Y. B. Ramakrishna. Their whole-hearted support led to several national-level consultations on formulating a national policy on biodiesel and a draft was sent to GoI. Some state governments also adopted the policy. Biodiesel Development Boards were set up in several states and provisions were made to build large communities that are well aware of the potential of biofuels for an environmentally sustainable future.

Is biodiesel being used in India? SuTRA started the campaign in 1997 and after so many years as of January 
2020 , a cumulative total of 160,000 tonnes of biodiesel has been blended, a difficult to appreciate progress. In conclusion, I can only write 'Sorry Professor Dhawan, I too missed the bus'.

It is worthwhile getting at least an explanation for the missed opportunity. The US started at about the same time as the rest. It, however, by an executive action let the sector grow freely. Anyone can manufacture and sell. The incentive is the substantial tax credit. India also started at the same time, but missed facilitating public participation in the development.

But there is still hope. The present Government, for instance, has come up with an innovative approach to address the bread labour. Virtually every villager got a Jan Dhan bank account, 40 crores at the last count. It is used for direct benefit transfer of any ongoing schemes. They are also allowed small loans, called Mudra loans, from banks, the amount depending on their borrowing history. They are thus encouraged to look for local opportunities and become entrepreneurs to earn their own bread labour. Appropriate technology generation at the grassroots by the millions. Finally, Sarvodaya is not an inappropriate suggestion; but it has taken long to find feasible approaches.

1. Bhat, V. V., Development Problem, Strategy, and Technology Choice: Sarvodaya and Socialist Approaches, World Bank, The University of Chicago Press, 1982.

2. Gopinathan Pillai, K., Gandhi and the concept of alternative technology. Indian J. Polit. Sci., 1988, 49(3).

ACKNOWLEDGEMENT. I thank to S. Tilottama for corrections, suggestions and general encouragement.

doi: $10.18520 / \mathrm{cs} / \mathrm{v} 119 / \mathrm{i} 9 / 1474-1478$ 